\title{
An examination of food parenting practices: structure, control and autonomy promotion
}

\author{
Dara R Musher-Eizenman*, Lynnel Goodman, Lindsey Roberts, Jenna Marx, \\ Maija Taylor and Debra Hoffmann \\ Department of Psychology, Bowling Green State University, Bowling Green, OH 43403, USA
}

Submitted 5 April 2018: Final revision received 6 September 2018: Accepted 23 0ctober 2018: First published online 18 December 2018

\begin{abstract}
Objective: In recent years, researchers have been working towards creating a standard conceptual framework of food parenting. To understand how parents' reports correspond with the proposed model, the current study examined parents' reports of their feeding behaviours in the context of a newly established framework of food parenting.

Design: Cross-sectional, with a two-week follow-up for a subset of the sample. Participants completed a quantitative and qualitative survey to assess food parenting. The survey included items from common food parenting instruments to measure the constructs posited in the framework. Exploratory factor analyses were conducted to ascertain which items related most closely to one another and factors were mapped on to existing constructs.

Setting: Online.

Participants: Parents of children aged $2 \cdot 5-7$ years ( $n$ 496). Of these, 122 completed a two-week follow-up.

Results: Analyses revealed eleven aspects of Structure (monitoring; distraction; family presence; meal/snack schedule; unstructured practices; healthy/unhealthy food availability; food preparation; healthy/unhealthy modelling; rules), ten aspects of Coercive Control (pressure to eat; using food to control emotions; food incentives to eat; food incentives to behave; non-food incentives to eat; restriction for health/weight; covert restriction; clean plate; harsh coercion) and seven aspects of Autonomy Promotion (praise; encouragement; nutrition education; child involvement; negotiation; responsive feeding; repeated offering). Content validity, assessed via parents' open-ended explanations of their responses, was high, and test-retest reliability was moderate to high. Structure and Autonomy Promoting food parenting were highly positively correlated.

Conclusions: In general, parents' responses provided support for the model, but suggested some amendments and refinements.
\end{abstract}

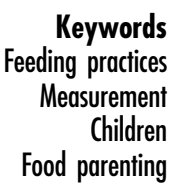

Several decades of research has found that parents play an important role in determining what their children eat, shaping their children's eating habits and impacting their children's weight outcomes ${ }^{(1-3)}$, referred to collectively as food parenting. In cross-sectional, longitudinal and intervention studies, researchers have examined both general food parenting style (e.g. permissive feeding, authoritarian feeding) and more specific feeding practices (e.g. restriction, pressure to eat), as well as how these practices relate to child health and weight-related outcomes (e.g. weight status, eating behaviours) ${ }^{(4-6)}$.

Despite consistent findings that parents play an important role in shaping their children's long-term eating and weight-related outcomes, specific findings have been mixed. These discrepancies may be due in part to different conceptualizations of food parenting. For example, a recent review ${ }^{(7)}$ identified seventy-nine published instruments (1392 items in total) for measuring food parenting practices. Across the instruments, researchers often used different labels for similar, overlapping and/or identical constructs (e.g. offering dessert in exchange for eating dinner is sometimes classified as 'food as reward' and other times classified as 'pressure to eat more'). Similarly, another review found that measures of food parenting practices vary widely in quality ${ }^{(8)}$. In response to the disparate nature of the food parenting literature, researchers $^{(9)}$ have concluded that the field needs to agree upon a single conceptualization of food parenting and use standard measures with strong psychometric properties.

To address this need, two valuable approaches have been initiated. First, O'Connor and colleagues ${ }^{(7)}$ began the development of an item bank for food parenting practices, 
comprising both published items and qualitative surveys of parents. Thus far, the authors have grouped the roughly 400 items generated into representative concepts (i.e. control, autonomy promotion, structure of food environment, responsiveness, consistency of feeding environment, behavioural and educational, and emotion regulation). Eventually, this item bank will be able to be used within a Computerized Adaptive Testing environment, where the presented items are tailored based on the responses given, so that participants can complete relevant items and results can be compared across studies.

Meanwhile, a second effort has approached this issue from a top-down direction. Namely, a team of experts collaborated to outline a content map to guide the conceptualization and naming of various food parenting practices $^{(10)}$. The resulting content map included three broad food parenting constructs: Coercive Control, Structure and Autonomy Promotion, each of which is comprised of several sub-constructs (see Fig. 1).

However, despite these important steps, little research has yet examined parents' reports of their use of the constructs and sub-constructs proposed in Vaughn et al.'s ${ }^{(10)}$ concept map. Thus, the goal of the current study was to measure the broad range of food parenting behaviours in the three domains identified in the conceptual framework (Structure, Control and Autonomy Promotion). Drawing from existing measures that map on to these constructs, we sought to examine the fit of this concept map to empirical data from mothers and fathers, to examine the stability of these reports over a short interval and to describe the extent and ways in which parents report using these practices.

\section{Methods}

\section{Measures}

Parents responded to 166 items, drawn from several sources. Items from three broad scales of food parenting practices were included: (i) the Comprehensive Feeding Practices Questionnaire (CFPQ; forty-nine items) ${ }^{(11)}$; (ii) the Meals in our Household structure subscale $(\mathrm{MioH}$; ten items) ${ }^{(12)}$; and (iii) the Feeding Strategies Questionnaire (FSQ; thirteen items) ${ }^{(13)}$. These measures were selected for their inclusion of the constructs described in the concept map. For example, most measures of food parenting do not include explicit measures of structure, so the items from the $\mathrm{MioH}$ were important to represent these aspects of the concept map. Some items from the $\mathrm{MioH}$ and the FSQ were not included because they duplicated CFPQ

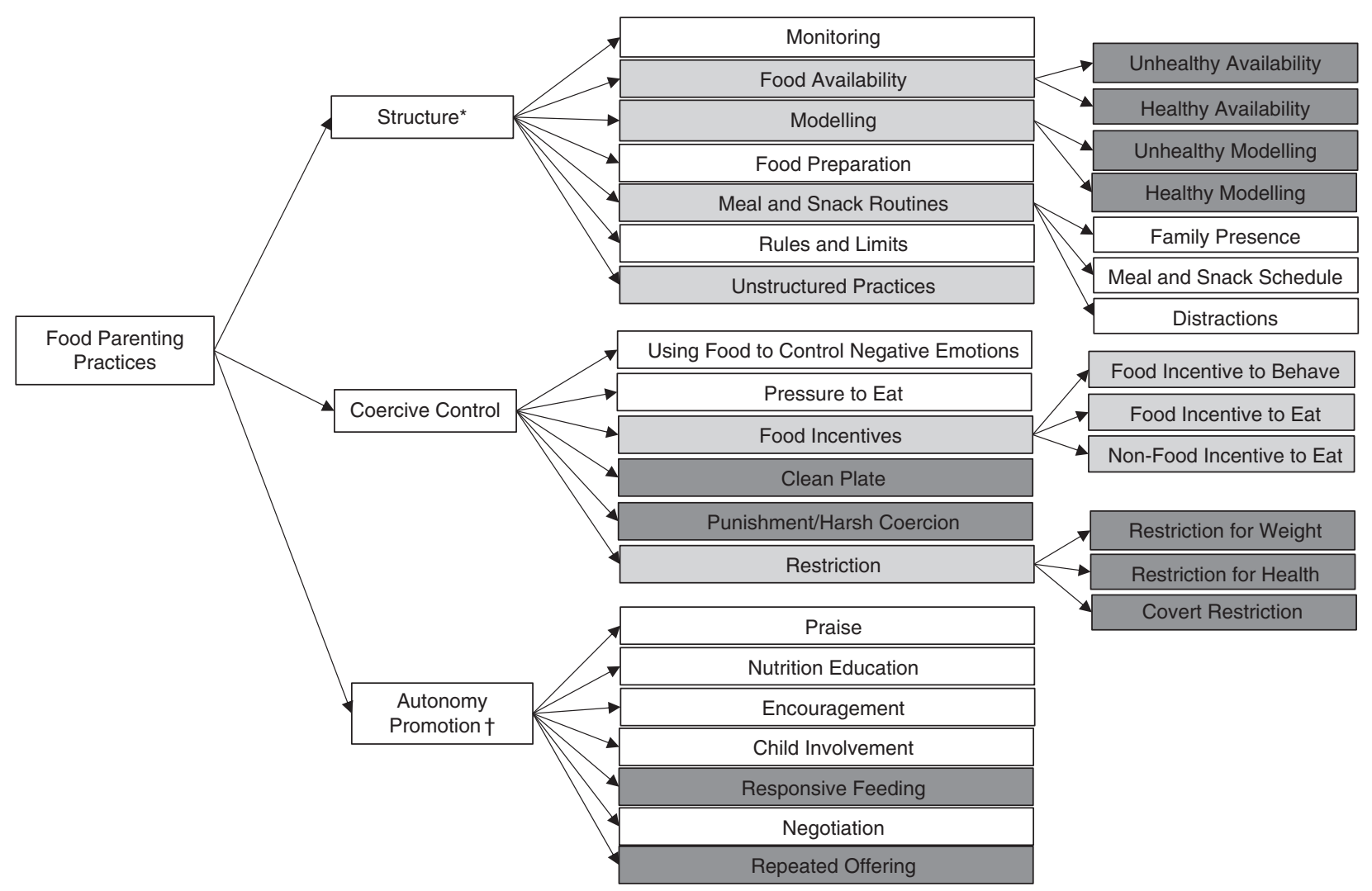

Fig. 1 Map of food parenting practices used in the present study ( $\square$, construct same as Vaughn et al. ${ }^{(10)}$; $\square$, construct similar to Vaughn et al. ${ }^{(10)} ; \square$, construct not represented in Vaughn et al. $\left.{ }^{(10)}\right)$. Constructs from Vaughn et al. ${ }^{(10)}$ not included in the present study: *Limited/Guided Choices, Atmosphere of Meals, Food Accessibility, Neglect and Indulgence (Structure); †Reasoning (Autonomy Support) 
items or they were not relevant to parental feeding practices (e.g. 'My child knows when s/he is full'). In addition, we reviewed items from published instruments and representative food parenting concepts reviewed by O'Connor et $a l .{ }^{(7)}$ that were not included in the above three instruments, which yielded an additional fifty-two items. Finally, we generated additional items (forty-two items) for the constructs outlined by Vaughn et al.'s ${ }^{(10)}$ concept map which were not well represented by the final item set and could not readily be found in extant measures of food parenting. All items were worded in the first person (e.g. 'I let my child ...') and most were measured on a 5-point scale from 'never' to 'always', except for items from the FSQ which were measured on a scale from 'strongly disagree' to 'strongly agree'.

\section{Data collection procedure}

Parents of 2.5-7-year-old children were recruited to participate. Children younger than 2 years have unique feeding issues that are not well captured by this concept map (e.g. bottle use) and children older than 8 years begin to make more independent eating decisions. Thus, this age range captures a typical range for the study of food parenting. Parents were recruited via Amazon's Mechanical Turk, an online platform where hundreds of thousands of members can complete jobs (such as surveys) over the Internet. Participants can be screened for specific characteristics such as US residency. Although Mturk has both strengths and limitations like any source of data ${ }^{(14)}$, several empirical studies have indicated that samples recruited in this manner match the demographics of the USA more closely than typical convenience or Internet samples and yield high-quality data ${ }^{(15-17)}$. Mturk has been used successfully to conduct research on eating habits in general and food parenting practices specifically ${ }^{(18,19)}$. Written informed consent was obtained from all participants. Parents who agreed to participate were given the link to the online survey hosted on Qualtrics. The first page of the survey presented an explanation of the general purpose, methods, and risks and benefits of the study, and explained that participants were indicating their informed consent by continuing to the first set of items. The survey included items about food parenting practices and demographic questions. It also featured several other questionnaires which were not examined in the present study. After participants completed the food parenting items, the survey software randomly selected four of the behaviours that the parent reported doing 'often' or 'always' and asked a set of open-ended, follow-up questions about these behaviours. All follow-up questions took the form of, 'Earlier you said that you often or always (e.g. offer your child his/her favourite foods in exchange for good behaviour). Please briefly tell us more about the last time that you did this.' Follow-up questions were intended to capture a qualitative view of parents' interpretation of the items to provide an understanding of how parents are using these food parenting practices with their children.

Data were screened for patterned responses (e.g. the same response for every item on a scale), incorrect responses to several quality control questions (e.g. please select 'agree' for this item), inappropriate responses to the open-ended questions (e.g. off-topic comments) and total survey completion time (under $10 \mathrm{~min}$ ). Fewer than $10 \%$ of those who completed the survey were rejected, with incorrect responses to quality control items being the most common reason (4\%). Participants were compensated \$US 0.75 for completion of the survey. Participants were also asked if they would like to complete a follow-up survey two weeks later for an additional \$US 0.25. This follow-up survey contained the food parenting items (other than the twentythree MioH and FSQ items which had been previously removed as they duplicated items from other scales or measured something other than parental feeding practices such as child satiety) to assess test-retest reliability ( $n$ 122). All procedures were approved by the Bowling Green State University Institutional Review Board prior to recruitment.

\section{Analysis procedure}

\section{Factor analysis and scale formation}

For each of the three broad domains, Pearson's $r$ correlations were calculated between the subscales to understand the bivariate relationships among these constructs. To test whether the a priori factor structure would fit the data, exploratory factor analyses with maximum likelihood extraction and promax rotation were conducted in IBM SPSS Statistics version 21 on subsets of items corresponding to the three broad domains of Coercive Control, Structure and Autonomy Promotion. Factor loadings were examined to ascertain which items related most closely to one another and, whenever possible, factors were mapped on to constructs defined by Vaughn et al. ${ }^{(10)}$ (see Fig. 1). The number of factors to retain was based on an examination of eigenvalues over 1 and the break point in the scree plot (which yielded the same number of factors in these models) Bivariate correlations among the three domains were also calculated to understand how Coercive Control, Structure and Autonomy Promotion related to one another in this sample.

\section{Qualitative responses}

Parents' responses on the open-ended questions were analysed through systematic coding. Three pairs of coders (all authors) initially coded responses based on whether the content of each individual response indicated that the participant understood the item, misunderstood the item, or provided unrelated or insufficient information (e.g. 'I did this yesterday', 'always'). Agreement was very high $(\kappa=0.99)$. Any discrepancies between coders were resolved by a third coder (one of the first four authors), blind to coding pairs. Open-ended items with five or more responses were analysed. 


\section{Test-retest reliability}

To examine the stability of parents' responses over a twoweek interval, Pearson's correlations were calculated between the subscale scores obtained at the two time points (i.e. the original sample and the subset of participants who completed the follow-up survey two weeks later).

\section{Results}

\section{Participant description}

The sample included 118 fathers and 376 mothers (and two parents who did not specify their gender) of children between the ages of 2.5 and 7 years (mean 4.7 (SD 1.1) years) living in the USA. The mean age of fathers was 33.0 (SD 7.0) years and of mothers was 32.4 (SD 6.5 ) years. The sample was geographically diverse, representing fortynine of the fifty states, with no more than $8 \%$ from any one state (California). The sample featured some racial diversity (79\% Caucasian, 8\% African-American, 5\% Multiracial, $4 \%$ Hispanic and $2 \%$ Asian). The median reported household income category was \$US 50 000-80000 (with $7.5 \%$ of the sample reporting an income of under \$US 20000 and $17.4 \%$ reporting an income of greater than $\$$ US $80000)$. The median educational attainment was an associate's degree (with $10.9 \%$ of the sample reporting a high-school education and $45.8 \%$ reporting at least a bachelor's degree). Of the original sample, 122 parents completed the follow-up survey. Those who completed the follow-up did not differ from those who did not on any demographic characteristics (all $P>0 \cdot 10$ ).

\section{Factor analyses}

Across the factor analyses, twenty items loaded below $0 \cdot 20$ on any factor and were therefore excluded from the final measure. The items that loaded below $0 \cdot 20$ on any factor can be found in Table 1 and the factor loadings for all remaining items can be found in Tables 2-4.

\section{Structure}

Vaughn et al.'s ${ }^{(10)}$ concept map for Structure included nine factors: rules and limits, limited/guided choices, monitoring, meal and snack routines, modelling, food availability, food accessibility, food preparation, and unstructured practices. The meal and snack routines factor was further broken down into the following factors: atmosphere of meals, distractions, family presence, and meal and snack schedule. The unstructured practices factor was further broken down into neglect and indulgence.

The factor analysis of the Structure items mapped well on to some of these constructs but less closely on to others. Five factors were replicated from the content map: monitoring, distraction, family presence, meal and snack schedule, and indulgence. However, unlike the content map, food availability and food accessibility loaded together and instead separate factors for healthy foods and unhealthy foods emerged for these two constructs. Similarly, modelling was also divided into the factors of healthy and unhealthy modelling. Three expected factors neglect, limited or guided choices, and atmosphere of meals - were not well represented by the current items, suggesting either that the scales used in the present study did not adequately encompass these constructs or that parents do not respond to these as distinct. Finally, although a rules and limits subscale emerged, the items focused on rules about mealtime behaviour rather than rules about food per se. Table 5 shows subscale means, SD and Cronbach's $\alpha$ values. Correlations among factors can be found in Table 6 .

The Structure subscales were significantly correlated with one another in expected directions (see Table 7). On average, parents reported high levels of healthy food

Table 1 Food parenting practice items that loaded below 0.20 on any factor in the current sample of mothers and fathers and were excluded from the final model

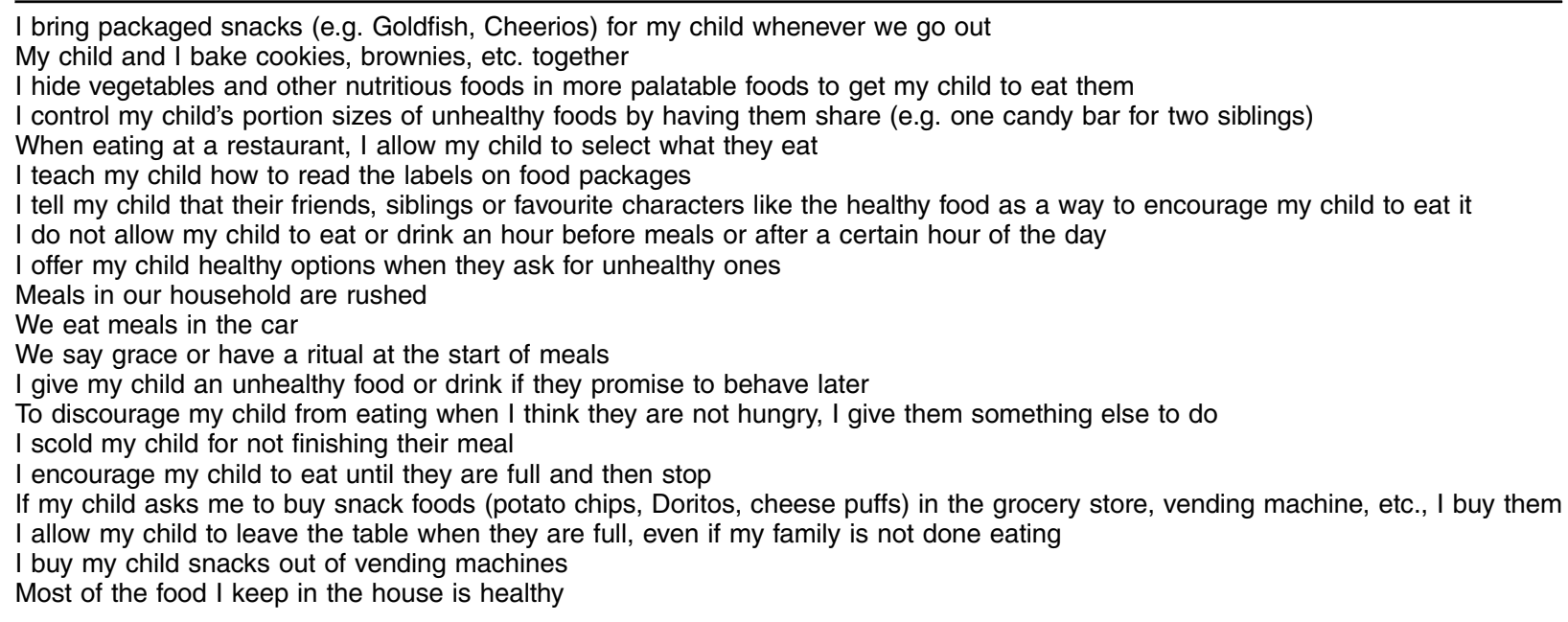


Table 2 Items and factor loadings of all food parenting items that loaded on Structure subscales

Factor

loading

Monitoring

I keep track of the sweets (candy, ice cream, cake, pies, pastries) that my child eats

I keep track of the snack food (potato chips, Doritos, cheese puffs) that my child eats

0.87

I keep track of the high-fat processed foods that my child eats

0.86

I keep track of the nutritious foods my child eats

0.85

I keep track of the fruits and vegetables my child eats

0.83

$\begin{array}{ll} & 0.81 \\ & 0.80\end{array}$

I keep track of the calcium, whole grains, protein, etc. my child consumes 0.65

Meal and snack schedule

My child's meals and snacks are scheduled each day 0.84

We eat meals at the same time every day 0.82

Mealtimes occur at the same time each day 0.76

A consistent feeding schedule is important to me at home

Snacks are offered at the same time every day 0.71

Our family eats an evening meal at a regular time $\quad 0.55$

My child is offered the same number of meals every day 0.54

Healthy food availability/accessibility

Fruit is available for my child to eat at home

kitchen for my child to eat (e.g. pre-cut, clean)

I make sure that I have healthy foods in the house that my child likes

0.86

0.83

pack healthy foods in my child's lunch bag for snacks and lunch at school 0.51

I choose places to eat out that have healthy options for my child 0.34

A variety of healthy foods are available to my child at each meal served at home 0.37

I prepare food in a healthy way for my family (e.g. steaming or baking instead of frying) 0.34

Unhealthy food availability/accessibility

I allow my child to eat unhealthy foods when we are on vacation 0.75

I have unhealthy food in the house that my child likes

Processed foods (e.g. boxed Mac and cheese, frozen pizza, chips) are available for my child to eat at home 0.70

I allow my child to eat unhealthy food when we are away from home (e.g. doing errands, driving to practices) 0.62

I keep a lot of snack food (potato chips, Doritos, cheese puffs) in my house 0.60

I keep a lot of sweets (candy, ice cream, cake, pies, pastries) in my house 0.50

I take my child to eat at fast-food restaurants 0.36

Distractions

My child frequently eats meals and snacks in front of the television 0.91

My child frequently eats meals and snacks in the living room or family room 0.85

The television is on and in the same room when my child is eating meals 0.82

Mealtimes are full of distractions at our house $\quad 0.48$

My child often has toys at the table during meals 0.42

Food preparation

I serve healthy foods (e.g. fruit) as dessert 0.84

I prepare healthful foods in a colourful, fun and/or creative way 0.80

I prepare healthful foods in a variety of ways 0.57

I convey to my child that healthy foods can be exciting and special (e.g. first fruit of a new season, healthy family recipes) 0.57

Unstructured practices/indulgence

If my child repeatedly asks me for a snack, I give them one 0.72

I allow my child to eat snacks whenever they want 0.72

I let my child eat whatever they want 0.64

At meals, I let my child choose the food they want from what is served 0.64

If my child does not like what is being served at meals, I offer them something else 0.66

I give in to my child's food demands after saying no 0.30

If my child asks me to buy sweets in the grocery store, vending machine, etc., I buy them 0.23

Healthy modelling

I show my child how much I enjoy eating healthy foods

I try to eat healthy foods in front of my child, even if they are not my favourite $\quad 0.83$

I try to show enthusiasm about eating healthy foods 0.79

I eat fruits and vegetables in front of my child 0.76

I model healthy eating for my child by eating healthy foods myself 0.68

Unhealthy modelling

My child often sees me eating too much 0.84

My child often sees me making bad food choices 0.73

I drink soft drinks (e.g. Coke) when I am with my child 0.56

I eat highly processed foods (e.g. chips, cookies) in front of my child 0.40

Rules and limits

My child knows what the rules for mealtime behaviour are 0.65

$\begin{array}{ll}\text { We have clear rules about behaviour at mealtime } & 0.60\end{array}$

My child has to come and sit at the table during meals 0.40 


\begin{tabular}{ll}
\hline & $\begin{array}{c}\text { Factor } \\
\text { loading }\end{array}$ \\
\hline Family presence & $0 \cdot 76$ \\
At meals, my child eats the same food as everyone else & 0.62 \\
Everyone in our household eats something different at meals & 0.65 \\
My child eats meals with myself or other family members & 0.63 \\
Someone in our household cooks meals & 0.35 \\
We eat meals in the kitchen or dining room
\end{tabular}

availability and healthy modelling and low levels of less healthy practices (unstructured practices, distractions, unhealthy food availability and monitoring).

\section{Coercive Control}

The concept map for Coercive Control included four factors (restriction, pressure to eat, threats and bribes, and using food to control negative emotions), with threats and bribes further broken down into three subscales (foodbased threats and bribes to eat, food-based threats and bribes to behave, and non-food incentives to eat).

The factor analysis of the Coercive Control items yielded eleven factors. Of these, five closely corresponded with those proposed in the content map: pressure to eat, using food to control negative emotions, and the three subscales that form threats and bribes. In addition, restriction emerged as three separate scales: restriction for health, restriction for weight and covert restriction. Two additional Coercive Control scales emerged: punishment/harsh coercion and clean plate. Finally, an eleventh factor included only two items, which cross-loaded on the covert restriction scale, so they were included with that scale for the sake of parsimony, leaving ten factors.

Most of the Coercive Control subscales were positively correlated with one another, except for covert restriction and restriction for health, which were uncorrelated with using food as an incentive and to control the child's emotions (see Table 8). On average, parents did not report high levels of Coercive Control. The highest subscale score was for restriction for health, with an average close to the midpoint of the 5-point scale (mean 3.34). Parents reported very low rates of restriction for weight control, using food to control their children's negative emotions and punishment/harsh coercion.

\section{Autonomy Promotion}

The concept map for Autonomy Promotion included six constructs: nutrition education, child involvement, encouragement, praise, reasoning and negotiation. However, in the factor analysis, these items loaded on to seven factors.

In the current analyses, five of the constructs were mapped closely; however, a reasoning factor did not emerge. In addition, two constructs not in the concept map were evident in the data: responsive feeding and repeated offering.
All the Autonomy Promotion subscales correlated positively with one another (see Table 9) and parents reported moderate to high use of all these food parenting practices.

\section{Correlations}

Correlations between the three broad constructs in the content map are shown in Table 6. A strong relationship emerged between the Structure construct and the Autonomy Promotion construct $(r=0 \cdot 53)$. Coercive Control and Structure were negatively correlated $(r=-0 \cdot 19)$.

Additionally, correlations between subscales across constructs were computed; most were small to moderate $(|r|=0 \cdot 01-0 \cdot 47)$. However, some stronger relationships were found between subscales from Structure and Autonomy Promotion. Specifically, healthy availability was positively related to nutrition education $(r=0.58)$, encouragement $(r=0.61)$ and child involvement $(r=0.50)$. Healthy modelling was positively related to encouragement $(r=0.63)$ and nutrition education $(r=0 \cdot 61)$. Finally, preparation was positively related to encouragement $(r=0.51)$, nutrition education $(r=0.56)$, child involvement $(r=0.58)$ and negotiation $(r=0.55)$.

\section{Test-retest reliability}

Subscale means and SD at time 1, Cronbach's $\alpha$ values at times 1 and 2, and test-retest reliability are given in Table 5. Test-retest correlations were compared with generally accepted standards ${ }^{(8)}$. Based on these standards, eight subscales demonstrated moderate test-retest reliability $(r=0.53-0.62)$ and sixteen subscales demonstrated strong test-retest reliability $(r=0 \cdot 70-0 \cdot 86)$.

\section{Qualitative responses}

Of items that received at least five open-ended responses, proportions of open-ended responses that indicated comprehension of the item ranged from 75 to $96 \%$. For a complete list of percentages of responses indicating understanding and samples of parents' responses to openended questions, see Table 10.

Although the open-ended responses generally demonstrated that parents had a good understanding of the items, an examination of items demonstrating lower rates of comprehension (under 70\%) is illustrative. These items did not cluster on a single construct (one each from food 
Table 3 Items and factor loadings of all food parenting items that loaded on Coercive Control subscales

\begin{tabular}{|c|c|}
\hline & $\begin{array}{l}\text { Factor } \\
\text { loading }\end{array}$ \\
\hline \multicolumn{2}{|l|}{ Using food to control negative emotions } \\
\hline I use food to soothe my child & 0.88 \\
\hline $\begin{array}{l}\text { I give my child a snack to keep them quiet even if I } \\
\text { think they are not hungry }\end{array}$ & $0 \cdot 81$ \\
\hline $\begin{array}{l}\text { When my child gets fussy, giving them something to } \\
\text { eat or drink the first thing I do }\end{array}$ & 0.79 \\
\hline $\begin{array}{l}\text { I give my child something to eat or drink if they are } \\
\text { upset even if I think they are not hungry }\end{array}$ & 0.64 \\
\hline I use food to cheer my child up & $0 \cdot 88$ \\
\hline $\begin{array}{l}\text { I give my child something to eat or drink if they are } \\
\text { bored even if I think they are not hungry }\end{array}$ & 0.64 \\
\hline \multicolumn{2}{|l|}{ Food-based incentives to behave } \\
\hline $\begin{array}{l}\text { I offer sweets (candy, ice cream, cake, pastries) to } \\
\text { my child as a reward for good behaviour }\end{array}$ & $0 \cdot 84$ \\
\hline $\begin{array}{l}\text { I withhold sweets/dessert from my child in response } \\
\text { to bad behaviour }\end{array}$ & 0.60 \\
\hline $\begin{array}{l}\text { I offer my child his/her favourite foods in exchange } \\
\text { for good behaviour }\end{array}$ & 0.57 \\
\hline $\begin{array}{l}\text { I take my child out for ice cream or give them other } \\
\text { food treats to celebrate (e.g. after winning a } \\
\text { sports game, after completing a big school } \\
\text { project) }\end{array}$ & 0.50 \\
\hline $\begin{array}{l}\text { I give my child food treats (e.g. M\&Ms) to encourage } \\
\text { them to complete tasks (e.g. practising an } \\
\text { instrument, doing chores) }\end{array}$ & 0.39 \\
\hline \multicolumn{2}{|l|}{ Food-based incentives to eat } \\
\hline $\begin{array}{l}\text { I promise to give my child a food they like in } \\
\text { exchange for eating a disliked food (e.g. if they } \\
\text { eat soup for lunch, they will get pizza for dinner) }\end{array}$ & $0 \cdot 61$ \\
\hline $\begin{array}{l}\text { I offer my child sweets (candy, ice cream, cake, } \\
\text { pastries) as a reward for trying new foods }\end{array}$ & $0 \cdot 82$ \\
\hline $\begin{array}{l}\text { I offer my child sweets (candy, ice cream, cake, } \\
\text { pastries) as a reward for eating fruits or vegetables }\end{array}$ & 0.73 \\
\hline $\begin{array}{l}\text { I give my child an unhealthy food or drink if they } \\
\text { promise to eat a healthy food later }\end{array}$ & 0.46 \\
\hline \multicolumn{2}{|l|}{ Non-food incentives to eat } \\
\hline $\begin{array}{l}\text { I offer my child a sticker, activity or other non-food } \\
\text { reward for trying new foods }\end{array}$ & 0.94 \\
\hline $\begin{array}{l}\text { I offer my child a sticker, activity or other non-food } \\
\text { reward for eating fruits or vegetables }\end{array}$ & 0.91 \\
\hline $\begin{array}{l}\text { I offer my child a sticker, activity or other non-food } \\
\text { reward in exchange for eating their whole meal }\end{array}$ & 0.66 \\
\hline \multicolumn{2}{|l|}{ Pressure to eat } \\
\hline $\begin{array}{l}\text { When they say they are finished eating, I try to get } \\
\text { my child to eat one or two more bites of food }\end{array}$ & 0.80 \\
\hline $\begin{array}{l}\text { If my child eats only a small helping, I try to get them } \\
\text { to eat more }\end{array}$ & $0 \cdot 78$ \\
\hline $\begin{array}{l}\text { If my child says, 'I'm not hungry', I try to get them to } \\
\text { eat anyway }\end{array}$ & 0.65 \\
\hline $\begin{array}{l}\text { I beg my child to eat at least something from his or } \\
\text { her plate }\end{array}$ & 0.48 \\
\hline \multicolumn{2}{|l|}{ Restriction for weight control } \\
\hline $\begin{array}{l}\text { I don't allow my child to eat between meals because } \\
\text { I don't want them to get fat }\end{array}$ & $0 \cdot 78$ \\
\hline $\begin{array}{l}\text { I give my child small helpings at meals to control } \\
\text { their weight }\end{array}$ & 0.81 \\
\hline I encourage my child to eat less so they won't get fat & 0.80 \\
\hline $\begin{array}{l}\text { There are certain foods my child shouldn't eat } \\
\text { because they will make my child fat }\end{array}$ & 0.69 \\
\hline $\begin{array}{l}\text { If my child eats more than usual at one meal, I try to } \\
\text { restrict their eating at the next meal }\end{array}$ & 0.75 \\
\hline $\begin{array}{l}\text { I restrict the food my child eats that might make } \\
\text { them fat }\end{array}$ & 0.63 \\
\hline $\begin{array}{l}\text { I often put my child on a diet to control their weight } \\
\text { Restriction for health }\end{array}$ & 0.63 \\
\hline $\begin{array}{l}\text { I have to be sure that my child does not eat too } \\
\text { many high-fat processed foods }\end{array}$ & 0.65 \\
\hline
\end{tabular}

Table 3 Continued

\begin{tabular}{|c|c|}
\hline & $\begin{array}{l}\text { Factor } \\
\text { loading }\end{array}$ \\
\hline $\begin{array}{l}\text { I have to be sure that my child does not eat too } \\
\text { many sweets (candy, ice cream, cake or pastries) }\end{array}$ & 0.59 \\
\hline $\begin{array}{l}\text { I guide or regulate my child's eating so that they do } \\
\text { not eat too many junk foods }\end{array}$ & 0.65 \\
\hline $\begin{array}{l}\text { I have to be sure that my child does not eat too } \\
\text { much of their favourite foods }\end{array}$ & 0.46 \\
\hline $\begin{array}{l}\text { I guide or regulate my child's eating so they do not } \\
\text { eat too much of their favourite foods }\end{array}$ & 0.46 \\
\hline \multicolumn{2}{|l|}{ Covert restriction } \\
\hline $\begin{array}{l}\text { I ask others not to give my child unhealthy food (e.g. } \\
\text { candy, sweets, salty snacks) }\end{array}$ & 0.62 \\
\hline I avoid eating unhealthy foods in front of my child & 0.36 \\
\hline $\begin{array}{l}\text { I keep unhealthy foods hidden so my child won't eat } \\
\text { them }\end{array}$ & 0.45 \\
\hline $\begin{array}{l}\text { I intentionally keep some foods out of my child's } \\
\text { reach }\end{array}$ & 0.20 \\
\hline \multicolumn{2}{|l|}{ Clean plate } \\
\hline $\begin{array}{l}\text { My child must eat all of their meal in order to have } \\
\text { dessert }\end{array}$ & 0.71 \\
\hline $\begin{array}{l}\text { My child must eat at least some vegetables in order } \\
\text { to have dessert }\end{array}$ & 0.50 \\
\hline $\begin{array}{l}\text { My child should always eat all of the food on their } \\
\text { plate }\end{array}$ & 0.60 \\
\hline I praise my child for eating their whole meal & 0.46 \\
\hline $\begin{array}{l}\text { I force my child to remain at the table until they have } \\
\text { eaten their whole meal }\end{array}$ & 0.38 \\
\hline \multicolumn{2}{|l|}{ Punishment/harsh coercion } \\
\hline I scold my child when they do not try a new food & 0.73 \\
\hline $\begin{array}{l}\text { I scold my child when they do not eat fruits or } \\
\text { vegetables }\end{array}$ & 0.76 \\
\hline $\begin{array}{l}\text { I show disapproval by arguing with or yelling at my } \\
\text { child for not eating healthy food }\end{array}$ & 0.65 \\
\hline $\begin{array}{l}\text { I punish my child (e.g. send away from table or } \\
\text { spank) if they do not want to finish a meal, taste a } \\
\text { food, or eat fruits and vegetables }\end{array}$ & 0.54 \\
\hline I use threats to get my child to eat & 0.72 \\
\hline I criticize my child about the food they eat & 0.80 \\
\hline $\begin{array}{l}\text { I make my child feel guilty when he or she doesn't } \\
\text { eat vegetables or finish his or her meal }\end{array}$ & 0.65 \\
\hline $\begin{array}{l}\text { I use scare tactics to discourage my child from } \\
\text { eating unhealthy foods }\end{array}$ & 0.67 \\
\hline $\begin{array}{l}\text { I tell my child I will take away privileges (e.g. screen } \\
\text { time) if they do not eat healthy food }\end{array}$ & $0 \cdot 31$ \\
\hline $\begin{array}{l}\text { I scold or show disapproval when my child eats too } \\
\text { much }\end{array}$ & 0.49 \\
\hline
\end{tabular}

to control negative emotions, food incentive to behave, food incentive to eat, punishment/harsh coercion, covert restriction, verbal encouragement and negotiation). However, several of these items relied on a specific temporal sequence (e.g. 'I give my child an unhealthy food or drink if they promise to eat a healthy food later') which might be too subtle for parents to respond to accurately on a survey (i.e. several parents were coded as not understanding the item if they gave an example of giving a child an unhealthy food after eating a healthy one).

\section{Discussion}

Using both qualitative and quantitative measures, the present study examined parents' reports of their use of 
Table 4 Items and factor loadings of all food parenting items that loaded on Autonomy Promotion subscales

\begin{tabular}{|c|c|}
\hline & $\begin{array}{l}\text { Factor } \\
\text { loading }\end{array}$ \\
\hline \multicolumn{2}{|l|}{ Praise } \\
\hline I praise my child when they eat fruits or vegetables & 0.77 \\
\hline I praise my child when they try a new food & 0.72 \\
\hline \multicolumn{2}{|l|}{ Verbal encouragement } \\
\hline $\begin{array}{l}\text { I encourage my child to eat healthy foods before } \\
\text { unhealthy ones }\end{array}$ & 0.72 \\
\hline I encourage my child to try new foods & 0.57 \\
\hline I encourage my child to eat a variety of foods & 0.89 \\
\hline I tell my child that healthy food tastes good & 0.49 \\
\hline $\begin{array}{l}\text { I offer my child healthy options when they ask for } \\
\text { unhealthy ones }\end{array}$ & 0.63 \\
\hline \multicolumn{2}{|l|}{ Nutrition education } \\
\hline $\begin{array}{l}\text { I discuss with my child why it's important to eat } \\
\text { healthy foods }\end{array}$ & 0.87 \\
\hline I discuss with my child the nutritional value of foods & 0.78 \\
\hline I teach my child about healthy eating habits & 0.70 \\
\hline $\begin{array}{l}\text { I teach my child that certain foods/drinks should } \\
\text { only be consumed in moderation }\end{array}$ & 0.40 \\
\hline $\begin{array}{l}\text { I tell my child that certain food or drinks are not } \\
\text { good for his or her health or teeth }\end{array}$ & 0.72 \\
\hline $\begin{array}{l}\text { I persuade my child to eat healthy foods by } \\
\text { explaining why it's important (e.g. you will feel } \\
\text { better, good for you, you'll grow big and strong, } \\
\text { do better at school) }\end{array}$ & $0 \cdot 70$ \\
\hline \multicolumn{2}{|l|}{ Child involvement } \\
\hline $\begin{array}{l}\text { I allow my child to help prepare family meals (e.g. } \\
\text { chopping, washing, etc.) }\end{array}$ & 0.82 \\
\hline My child and I cook healthy foods together & 0.83 \\
\hline $\begin{array}{l}\text { I involve my child in planning family meals (e.g. } \\
\text { what meals will be served) }\end{array}$ & 0.69 \\
\hline $\begin{array}{l}\text { I encourage my child to participate in grocery } \\
\text { shopping. (e.g. picking out specific items) }\end{array}$ & 0.66 \\
\hline $\begin{array}{l}\text { I involve my child in gardening or picking fruits and } \\
\text { vegetables at a farm }\end{array}$ & 0.43 \\
\hline $\begin{array}{l}\text { I let my child choose fruits and vegetables while } \\
\text { shopping }\end{array}$ & 0.40 \\
\hline \multicolumn{2}{|l|}{ Responsive feeding } \\
\hline $\begin{array}{l}\text { If my child is truly hungry, I give them something to } \\
\text { eat even if it is not a regular meal or snack time }\end{array}$ & 0.65 \\
\hline $\begin{array}{l}\text { I allow my child to have seconds if they finish } \\
\text { foods from their plate at dinner and are still hungry }\end{array}$ & 0.66 \\
\hline $\begin{array}{l}\text { At meals, I allow my child to decide how much they } \\
\text { eat }\end{array}$ & 0.43 \\
\hline I ask my child if they are hungry before offering food & 0.36 \\
\hline $\begin{array}{l}\text { I encourage my child to pay attention to } \\
\text { hunger cues to decide when and how much } \\
\text { to eat }\end{array}$ & $0 \cdot 21$ \\
\hline \multicolumn{2}{|l|}{ Repeated offering } \\
\hline $\begin{array}{l}\text { If my child does not like a new food the first time I } \\
\text { serve it, I offer it repeatedly to encourage them to } \\
\text { accept it }\end{array}$ & 0.99 \\
\hline $\begin{array}{l}\text { When introducing a new food, I offer the item at } \\
\text { least ten (10) times to my child }\end{array}$ & 0.49 \\
\hline \multicolumn{2}{|l|}{ Negotiation } \\
\hline $\begin{array}{l}\text { I encourage my child to eat vegetables by playing } \\
\text { games at mealtimes or by challenging them to } \\
\text { eat it }\end{array}$ & 0.75 \\
\hline $\begin{array}{l}\text { I help my child set goals to eat more/new fruits and } \\
\text { vegetables }\end{array}$ & $0 \cdot 61$ \\
\hline $\begin{array}{l}\text { To encourage my child to eat a particular healthy } \\
\text { food (e.g. vegetables), I serve it with foods my } \\
\text { child likes }\end{array}$ & 0.50 \\
\hline $\begin{array}{l}\text { I give my child small portions to get them to eat a } \\
\text { particular food or new food }\end{array}$ & 0.33 \\
\hline $\begin{array}{l}\text { I allow my child to flavour healthy foods to make } \\
\text { them taste better (e.g. with dips, cheese sauce, } \\
\text { etc.) }\end{array}$ & 0.27 \\
\hline
\end{tabular}

parental feeding practices for 2.5-7-year-old children as described in the conceptual framework presented by Vaughn and colleagues ${ }^{(10)}$. We measured twenty-eight dimensions across the parental feeding areas of Structure, Control and Autonomy Promotion. Our results provide insight into the extent to which and how parents are using these food parenting practices in their interactions with their children.

A great deal of the past research on food parenting has focused on subscales that are considered here as part of the Coercive Control construct. For example, restriction and pressure to eat are included in the widely used Child Feeding Questionnaire ${ }^{(20)}$. Food incentives and using food to regulate children's emotions have also received a lot of attention by researchers ${ }^{(21)}$. The current study added two additional subscales to this domain, which were not included by Vaughn et al. ${ }^{(10)}$ : insisting that children clean their plate and punishment/harsh coercion. Because clean plate was one of the most highly endorsed Coercive Control subscales, and because the harsh coercion items are so severe in nature, both these subscales hold tremendous promise for understanding aspects of parental feeding that have not been well considered to date.

Less research has focused on the structural aspects of parental feeding practices. Recent research suggests that in addition to warmth and control, structure (e.g. clear and consistent rules, routines) represents a third major dimension of general parenting and is an important predictor of child outcomes ${ }^{(22)}$. Similarly, available research supports the general finding that when parents create a healthy structure surrounding food (e.g. high availability of healthy foods, family meals together free of distractions), children show better dietary outcomes ${ }^{(23-25)}$. A recent study examining the structure component of this model found that structure-related feeding practices predicted child self-regulation in eating in children of pre-school $\operatorname{age}^{(26)}$.

The measures of the Structure subscales found here closely parallel those proposed by Vaughn et al. ${ }^{(10)}$. The primary exception was the finding that both modelling and availability separated into healthy and unhealthy subscales. For example, parents who reported keeping healthy foods in the house sometimes also reported keeping unhealthy foods in the house. Because dietary goals for children would include both increasing consumption of fruits and vegetables and limiting intake of nutrient-poor foods, looking at both unhealthy and healthy modelling and availability is important. Furthermore, although parents did report on rules, the content tended to differ from that proposed by Vaughn et al. ${ }^{(10)}$, who focused on rules about what, where, when and how much children should eat. The items included here focused primarily on rules for mealtime behaviour. Thus, this component might need further exploration, including expansion to examine eating behaviours outside mealtimes (i.e. snacking). 
Table 5 Means and SD, Cronbach's a values and test-retest reliability for all subscales within the Coercive Control, Structure and Autonomy Promotion domains

\begin{tabular}{|c|c|c|c|c|c|}
\hline & T1 Mean & $\mathrm{T} 1 \mathrm{SD}$ & $\mathrm{T} 1 \mathrm{a}$ & $\mathrm{T} 2 a$ & $r$ \\
\hline \multicolumn{6}{|l|}{ Coercive Control } \\
\hline Food to control negative emotions & 1.79 & 0.73 & $0.90^{*}$ & $0.91^{*}$ & $0.56^{*}$ \\
\hline Food incentive to behave & 2.47 & 0.80 & $0.77^{*}$ & $0.77^{*}$ & $0.71^{*}$ \\
\hline Food incentive to eat & 1.90 & 0.83 & $0.86^{*}$ & $0.90^{*}$ & $0.65^{\star}$ \\
\hline Non-food incentive to eat & $2 \cdot 17$ & 1.10 & $0.90^{*}$ & $0.88^{*}$ & $0.66^{*}$ \\
\hline Punishment/harsh coercion & 1.66 & 0.70 & $0.90^{*}$ & $0.92^{*}$ & $0.72^{*}$ \\
\hline Clean plate & 3.04 & 0.82 & $0.73^{\star}$ & $0.73^{\star}$ & $0.86^{*}$ \\
\hline Restriction for weight control & 1.80 & 0.77 & $0.87^{*}$ & $0.91^{*}$ & $0.82^{*}$ \\
\hline Restriction for health & 3.34 & 0.77 & $0.74^{*}$ & $0.82^{*}$ & $0.58^{*}$ \\
\hline Covert restriction & 3.17 & 0.80 & $0.60^{*}$ & $0.64^{\star}$ & $0.82^{*}$ \\
\hline Pressure & 2.74 & 0.84 & $0.77^{\star}$ & $0.78^{\star}$ & $0.72^{*}$ \\
\hline \multicolumn{6}{|l|}{ Structure } \\
\hline Availability of unhealthy food & $2 \cdot 74$ & 0.67 & $0.85^{*}$ & $0.85^{\star}$ & $0.77^{*}$ \\
\hline Availability of healthy food & $4 \cdot 13$ & 0.61 & $0.87^{*}$ & $0.83^{*}$ & $0.71^{*}$ \\
\hline Unstructured practices & 2.43 & 0.66 & $0.78^{*}$ & $0.77^{\star}$ & $0.70^{*}$ \\
\hline Healthy modelling & 4.06 & 0.71 & $0.87^{\star}$ & $0.88^{*}$ & $0.75^{\star}$ \\
\hline Unhealthy modelling & 2.54 & 0.75 & $0.75^{\star}$ & $0.76^{\star}$ & $0.80^{*}$ \\
\hline Monitoring & 3.68 & 0.95 & $0.91^{*}$ & $0.94^{*}$ & $0.57^{*}$ \\
\hline Food preparation & 3.66 & 0.76 & $0.79^{\star}$ & $0.83^{\star}$ & $0.78^{*}$ \\
\hline Family presence & 3.85 & 0.68 & $0.78^{*}$ & - & - \\
\hline Meal and snack schedule & 3.67 & 0.75 & $0.87^{*}$ & - & - \\
\hline Distractions & $2 \cdot 34$ & 0.90 & $0.83^{*}$ & _- & - \\
\hline Rules and limits & 4.01 & 0.76 & $0.78^{*}$ & - & - \\
\hline \multicolumn{6}{|l|}{ Autonomy Promotion } \\
\hline Praise & 4.25 & 0.81 & 0.75 & 0.68 & $0.54^{*}$ \\
\hline Verbal encouragement & 4.22 & 0.62 & $0.84^{*}$ & $0.80^{*}$ & $0.53^{*}$ \\
\hline Nutrition education & 3.93 & 0.74 & $0.86^{*}$ & $0.84^{\star}$ & $0.62^{*}$ \\
\hline Child involvement & 3.47 & 0.78 & $0.82^{*}$ & 0.86 & $0.79^{*}$ \\
\hline Responsive feeding & 3.66 & 0.63 & $0.61^{*}$ & $0.67^{*}$ & $0.59^{*}$ \\
\hline Repeated offer & 3.24 & 0.94 & 0.71 & 0.83 & $0.65^{\star}$ \\
\hline Negotiation & 3.35 & 0.69 & $0.64^{*}$ & $0.62^{*}$ & $0.61^{*}$ \\
\hline
\end{tabular}

T1, time 1 ( $n$ 494); T2, time 2 ( $n$ 122).

*Indicates $P<0.001$.

Table 6 Bivariate correlations among Structure, Control and Autonomy Promotion domains of food parenting practices

\begin{tabular}{lccc}
\hline & Structure & Control & Autonomy Promotion \\
\hline Structure & - & & \\
Control & $-0.19^{*}$ & - & \\
Autonomy Promotion & $-0.53^{*}$ & 0.05 & - \\
\hline
\end{tabular}

*Indicates $P<0.001$.

Perhaps the greatest contribution of the Vaughn et $a{ }^{(10)}$ framework is the inclusion of food parenting behaviours that promote autonomy in the eating behaviours of children. Although many parents are concerned with the short-term goal of getting their child to eat more healthy and fewer unhealthy foods, many would agree that teaching children to make lifelong healthy eating decisions for themselves is also important ${ }^{(27)}$. Thus, understanding and measuring how parents achieve this longer-term goal is imperative. Two subscales that emerged in the present study, which were not represented in the Vaughn et al. ${ }^{(10)}$ framework, were responsive feeding and repeated offering. In a review of thirty-one studies, Hurley et $a l^{(28)}$ report that the majority found significant associations between responsive feeding and lower child adiposity. Furthermore, a large literature base demonstrates that offering a novel food many times improves children's acceptance and liking of that food ${ }^{(29)}$.

Since the data here were collected, two additional advances have been made in the direction of mapping and measuring food parenting practices. First, O'Connor et $a l .{ }^{(30)}$ recruited a panel of experts to sort survey items into the constructs proposed by the framework used here. This sorting procedure yielded five Control clusters, nine Structure clusters and three Autonomy Promotion clusters. Meanwhile, Vaughn et al. ${ }^{(31)}$ offered a new measure, the HomeSTEAD, comprising five Coercive Control practices, twelve Structure practices and seven Autonomy Promoting practices. The empirically derived subscales were similar, though not identical, to those proposed in the concept map. For example, as in our 
Table 7 Bivariate correlations between the subscales in the Structure domain of food parenting practices

\begin{tabular}{|c|c|c|c|c|c|c|c|c|c|c|c|}
\hline & 1 & 2 & 3 & 4 & 5 & 6 & 7 & 8 & 9 & 10 & 11 \\
\hline 1. Monitoring & - & & & & & & & & & & \\
\hline 2. Unhealthy availability & $-0.24^{\star \star}$ & - & & & & & & & & & \\
\hline 3. Healthy availability & $-0.37^{\star \star}$ & $-0.35^{\star *}$ & - & & & & & & & & \\
\hline 4. Unhealthy modelling & $-0.22^{\star \star}$ & $-0.63^{\star \star}$ & $-0 \cdot 38^{\star *}$ & - & & & & & & & \\
\hline 5. Healthy modelling & $-0.39^{\star \star}$ & $-0.31^{\star \star}$ & $-0.61^{\star \star}$ & $-0.40^{\star *}$ & - & & & & & & \\
\hline 6. Food preparation & $-0 \cdot 37^{\star \star}$ & $-0.40^{\star *}$ & $-0.64^{\star *}$ & $-0 \cdot 36^{\star *}$ & $-0.58^{\star *}$ & - & & & & & \\
\hline 7. Family presence & $-0 \cdot 16^{\star \star}$ & $-0.20^{\star \star}$ & $-0.41^{\star *}$ & $-0.23^{\star *}$ & $-0.31^{\star *}$ & $-0.29^{\star \star}$ & - & & & & \\
\hline 8. Meal/snack schedule & $-0 \cdot 29^{\star \star}$ & $-0.20^{\star *}$ & $-0.36^{\star \star}$ & $-0.23^{\star *}$ & $-0 \cdot 28^{\star *}$ & $-0.33^{\star \star}$ & $-0.42^{\star \star}$ & - & & & \\
\hline 9. Distractions & $-0 \cdot 13^{\star \star}$ & $-0.41^{\star *}$ & $-0.32^{\star \star}$ & $-0 \cdot 39^{\star *}$ & $-0.80^{* *}$ & $-0.26^{\star *}$ & $-0.53^{\star \star}$ & $-0.33^{\star \star}$ & - & & \\
\hline 10. Rules & $-0.27^{\star \star}$ & $-0.12^{\star \star}$ & $-0.31^{\star \star}$ & $-0 \cdot 17^{\star \star}$ & $-0.30^{\star \star}$ & $-0.28^{\star \star}$ & $-0.57^{\star \star}$ & $-0.52^{\star \star}$ & $-0.47^{\star \star}$ & - & \\
\hline 11. Unstructured practices & $-0 \cdot 15^{\star \star}$ & $-0.39^{\star \star}$ & $-0.20^{\star \star}$ & $-0 \cdot 32^{* *}$ & $-0 \cdot 18^{\star \star}$ & $-0 \cdot 16^{\star \star}$ & $-0.45^{\star \star}$ & $-0.27^{\star \star}$ & $-0.45^{\star \star}$ & $-0 \cdot 36^{\star \star}$ & - \\
\hline
\end{tabular}

Table 8 Bivariate correlations between the subscales in the Control domain of food parenting practices

\begin{tabular}{|c|c|c|c|c|c|c|c|c|c|c|}
\hline & 1 & 2 & 3 & 4 & 5 & 6 & 7 & 8 & 9 & 10 \\
\hline 1. Food to control emotions & - & & & & & & & & & \\
\hline 2. Pressure to eat & $0.37^{\star *}$ & - & & & & & & & & \\
\hline 3. Food incentive to behave & $0.50^{\star *}$ & $0.41^{* *}$ & - & & & & & & & \\
\hline 4. Food incentive to eat & $0.61^{\star *}$ & $0.37^{\star *}$ & $-0 \cdot 61^{\star *}$ & - & & & & & & \\
\hline 5. Non-food incentive to eat & $0.27^{\star \star}$ & $0.21^{\star \star}$ & $-0.35^{\star \star}$ & $0.39^{* *}$ & - & & & & & \\
\hline 6. Clean plate & $0.22^{\star *}$ & $0.45^{\star \star}$ & $-0 \cdot 36^{\star *}$ & $0.30^{\star *}$ & $0.30^{\star *}$ & - & & & & \\
\hline 7. Punishment/harsh coercion & $0.54^{\star *}$ & $0.44^{\star \star}$ & $-0.48^{\star *}$ & $0.58^{\star \star}$ & $0.36^{\star *}$ & $0.38^{\star *}$ & - & & & \\
\hline 8. Restriction for weight & $0.32^{* *}$ & $0.11^{\star *}$ & $-0 \cdot 15^{\star *}$ & $0.26^{\star *}$ & $0.30^{\star *}$ & $0.14^{\star *}$ & $0.45^{\star *}$ & - & & \\
\hline 9. Restriction for health & $0.06^{\star *}$ & $0.24^{\star *}$ & $-0.01^{\star *}$ & $0.00^{* *}$ & $0.19^{\star \star}$ & $0 \cdot 15^{\star *}$ & $0.15^{\star *}$ & $0.33^{\star *}$ & - & \\
\hline 10. Covert restriction & $0.04^{\star *}$ & $0.04^{\star \star}$ & $-0.03^{\star *}$ & $0.04^{\star *}$ & $0.29^{\star \star}$ & $0.17^{\star \star}$ & $0 \cdot 12^{\star *}$ & $0.25^{\star \star}$ & $0.36^{\star \star}$ & - \\
\hline
\end{tabular}

Table 9 Bivariate correlations between the subscales in the Autonomy Promotion domain of food parenting practices

\begin{tabular}{|c|c|c|c|c|c|c|c|}
\hline & 1 & 2 & 3 & 4 & 5 & 6 & 7 \\
\hline 1. Praise & - & & & & & & \\
\hline 2. Nutrition education & $0.43^{\star *}$ & - & & & & & \\
\hline 3. Encouragement & $0.54^{\star \star}$ & $0.62^{\star \star}$ & - & & & & \\
\hline 4. Child involvement & $0.27^{\star \star}$ & $0.51^{\star \star}$ & $0.39^{\star *}$ & - & & & \\
\hline 5. Responsive feeding & $0 \cdot 26^{\star \star}$ & $0 \cdot 37^{\star \star}$ & $0.39^{\star *}$ & $0.30^{\star *}$ & - & & \\
\hline 6. Negotiation & $0.37^{\star \star}$ & $0.44^{\star *}$ & $0.43^{\star *}$ & $0.39^{\star *}$ & $0.30^{\star *}$ & - & \\
\hline 7. Repeated offering & $0.22^{\star \star}$ & $0.22^{\star \star}$ & $0.36^{\star \star}$ & $0.20^{\star \star}$ & $0.29^{\star \star}$ & $0.34^{\star *}$ & - \\
\hline
\end{tabular}

data, a 'clean plate' subscale emerged in Vaughn et al.'s instrument, emphasizing its distinct relevance to parents, as differentiated from, for example, pressure to eat. Taken together, these studies reinforce the value of continuing to seek a convergence between top-down (expert driven) and bottom-up (data driven) approaches to understanding food parenting.

In addition to the quantitative findings here, a review of the qualitative data demonstrated that most parents put a great deal of thought and effort into feeding their children and desired to communicate this through examples. This was true even when the specific item did not apply to their individual situation. For example, in responding to the item asking for examples of 'packing healthy foods in your child's lunch/snacks for school', parents whose children did not attend school provided examples of packing healthy snacks at other times when their child is away from home. Similarly, in responding to the item asking for examples of 'helping your child set goals to eat more/new fruits and vegetables', parent responses were enthusiastic about sharing methods to achieve this goal but infrequently included an example of specific, collaborative goal setting. However, these responses provide rich information that can contribute to our understanding of parent attitudes towards feeding and feeding practices. It was clear from these data that parents' perspectives must be included in efforts to accurately capture food parenting.

The present study had several strengths. First, the research was driven by and the results aligned closely with the concept map for parental feeding proposed by Vaughn and colleagues ${ }^{(10)}$. As such, the results present a strong framework within which to examine parental feeding practices. Second, unlike many existing approaches to 
Table 10 Sample responses from parents describing the last time they used a particular food parenting practice, and the percentage of qualitative responses that indicated comprehension of the items by subscale

\begin{tabular}{|c|c|c|}
\hline Subscale & $\begin{array}{c}\text { Proportion of responses } \\
\text { indicating comprehension (\%) }\end{array}$ & Sample responses \\
\hline $\begin{array}{l}\text { Food to control } \\
\text { negative emotions }\end{array}$ & 88 & $\begin{array}{l}\text { 'He got a lollipop the last time he fell and scraped his knees.' } \\
\text { 'I gave [my child] candy when she cried on the train the other day.' } \\
\text { 'Bought ice cream after he got a shot that was painful.' }\end{array}$ \\
\hline $\begin{array}{l}\text { Food incentive to } \\
\text { behave }\end{array}$ & 93 & $\begin{array}{l}\text { 'My child was very nice to a classmate and so I took him out for ice cream.' } \\
\text { 'She gets an M\&M or Skittle each day for practising writing her name/letters of the } \\
\text { alphabet.' } \\
\text { 'I gave him a lollipop for putting on his own shoes.' }\end{array}$ \\
\hline $\begin{array}{l}\text { Food incentive to } \\
\text { eat }\end{array}$ & 90 & $\begin{array}{l}\text { 'I gave him some M\&Ms for eating all his veggies.' } \\
\text { 'I gave my daughter something that she enjoyed for dinner in exchange for eating a } \\
\text { healthier lunch at home.' } \\
\text { 'Wife cooked something that made us all a little nervous. I offered a better meal } \\
\text { later if they gave the new meal try.' }\end{array}$ \\
\hline $\begin{array}{l}\text { Non-food incentive } \\
\text { to eat }\end{array}$ & 96 & $\begin{array}{l}\text { 'My daughter ate her broccoli last week, and then I took her to the park as a reward.' } \\
\text { 'I give hugs and high fives for finishing all of the vegetables on the plate.' } \\
\text { 'I offer her time on her Kindle for trying new foods. I add two minutes for every bite. } \\
\text { So if she eats five bites of a food she dislikes, she gets ten extra minutes of Kindle } \\
\text { time.' }\end{array}$ \\
\hline $\begin{array}{l}\text { Punishment/harsh } \\
\text { coercion }\end{array}$ & 75 & $\begin{array}{l}\text { 'The rule is that our son has to taste one bite of a new food. If he refuses, he must } \\
\text { go to his room until he is ready to try the food.' } \\
\text { 'I took his tablet away because he refused to try dinner.' }\end{array}$ \\
\hline Covert restriction & 84 & $\begin{array}{l}\text { 'When my child has a play-date, I make sure to tell the parent my eating wishes for } \\
\text { my child.' } \\
\text { 'I tell the grandparents to stop giving them unhealthy treats and getting them } \\
\text { sugared up. Yesterday in fact.' } \\
\text { 'I know my friend has a lot of junk food in his house, so I told him to get something } \\
\text { healthy for when my child stayed over.' }\end{array}$ \\
\hline Healthy modelling & 85 & $\begin{array}{l}\text { 'My husband and I make an especially big deal of exclaiming how yummy the } \\
\text { healthiest part of the meal is.' }\end{array}$ \\
\hline Food preparation & 94 & $\begin{array}{l}\text { 'I make fun foods like stuffed bell peppers that are shaped like jack o' lanterns } \\
\text { during Halloween. Or I make wholegrain pancakes in fun shapes (e.g. hearts for } \\
\text { Valentine's Day!)' } \\
\text { 'I tried to make a vegetable and fruit platter incorporating all the colours that [my } \\
\text { child] knows. We went over colours and would eat everything that was red, then } \\
\text { everything green, etc.' } \\
\text { 'I (within the last couple of weeks) learned how to cut up an apple so it looks like a } \\
\text { swan and I am learning how to cut up other fruits, vegetables and foods so that they } \\
\text { look like animals and stuff (trying to learn two per week).' } \\
\text { 'We went shopping together and had fun picking out everything to make a big salad. } \\
\text { Then at home we chopped and diced and had some music playing and it was a fun } \\
\text { time.' }\end{array}$ \\
\hline Praise & 90 & $\begin{array}{l}\text { 'I praise him when he tried a new type of food, even if he doesn't like it, which is fine. } \\
\text { I just want him to feel good about trying!' } \\
\text { 'When my child ate apple slices after several attempts, I clapped and yelled } \\
\text { "hooray!" }\end{array}$ \\
\hline $\begin{array}{l}\text { Verbal } \\
\quad \text { encouragement }\end{array}$ & 90 & $\begin{array}{l}\text { 'I found dragon fruit in the store for the first time, so I bought one to try. It looked odd } \\
\text { and he wasn't sure about trying it, but I encouraged him and he ate some. I told him } \\
\text { what a good job he did being brave and tasting it.' }\end{array}$ \\
\hline Nutrition education & 95 & $\begin{array}{l}\text { 'Discussed why eating her veggies would help her grow and make it easier to learn } \\
\text { in school because of the vitamins.' } \\
\text { 'At every meal we talk about why the protein and vegetable on our plate are } \\
\text { important for our bodies.' } \\
\text { 'The last time I did this, I was explaining why we drink milk because the calcium and } \\
\text { vitamins A and D are good for our bones and other parts of our body.' }\end{array}$ \\
\hline Negotiation & 84 & $\begin{array}{l}\text { 'A few days ago we played "Around the Plate". This is where we take one bite from } \\
\text { each thing all the way around the plate and repeat, etc.' } \\
\text { 'Telling him to pretend to be a monster and eat broccoli like they were tiny trees.' } \\
\text { 'When she tried cauliflower for the first time, we told her that we bet her that she } \\
\text { couldn't eat the entire serving we gave her. If she did, she could paint Daddy's } \\
\text { fingernails like she always wanted too.' }\end{array}$ \\
\hline
\end{tabular}

Percentages are listed only for those subscales where at least half of the items received a sufficient number of follow-up responses (i.e. at least five responses per item).

food parenting that focus solely on negative feeding practices, the present study assessed both beneficial and detrimental feeding practices. The open-ended items showed that parents are engaging in many positive feeding practices, which suggests that if we hope to obtain a comprehensive and accurate understanding of how parents feed their children, assessing positive feeding practices is necessary. Third, although the sample is drawn 
only from individuals who use the crowd sourcing website, MTurk, the large, nationwide sample that included both mothers and fathers of children aged 2-7 years is likely representative of typical caregiver feeding practices. Furthermore, the current study is one of few studies on parent feeding that included fathers.

Although the study had several strengths, there are also a few limitations worth noting. First, the nature of the data is self-report, which means that it is subject to biases and mental errors. These reporting biases may be apparent in the low rates of endorsement for less socially desirable food parenting practices. The authors recommend that future research examining parenting practices uses observational data as well, and compares findings. Second, the measurement of these constructs could benefit from further improvement. For example, some subscales still demonstrate lower-than-preferred reliability and validity. Additional cognitive testing of the items would likely strengthen the measurement. Finally, food parenting is likely impacted by the parent-child relationship, child temperament and other dyadic factors. Future research should consider exploring the interactive nature of feeding occasions and how this contributes to parental feeding.

Despite these limitations, the results presented here contribute significantly to the understanding of caregiver feeding of children aged 2-7 years, and open the door to a multitude of future research projects. Although our sample was moderately large, it was limited to parents of 2-7year-olds and parents and children were mostly Caucasian; therefore, future research would benefit from measuring food parenting in this way across other caregivers (e.g. grandparents, childcare teachers), child age ranges and cultures. Future investigation could also clarify how child weight, health parameters and health behaviours are related to parent feeding practices described in this framework. Similarly, more exploration of the bidirectional relationship between child factors and parent feeding is needed. A longitudinal or matched cohort study including both predictive and outcome factors would further illuminate the complex parental feeding-child outcome relationship.

Although the wide variety of instruments and conceptual approaches used in food parenting research has made it difficult to compare across studies, it has also provided opportunities to examine research questions from multiple perspectives. Ultimately, this might have encouraged progress in the field, which would not have been achieved had a single measure or model dominated the research. Nevertheless, as our understanding of food parenting has progressed, the widespread desire to frame and measure constructs in a more consistent, coherent and comprehensive way has become salient. While we do not imagine that this approach is the last that will be offered, it does begin the process of merging a concept map agreed upon by many experts in the field and empirically based perspectives. Thus, we hope that the results presented here will continue to move this collaborative discussion forward to inform future measurement and research in the important domain of food parenting.

\section{Acknowledgements}

Financial support: This research received no specific grant from any funding agency in the public, commercial or notfor-profit sectors. Conflict of interest: None. Authorship: D.R.M.-E. oversaw all aspects of the study and the writing of the manuscript. L.G., L.R., J.M., M.T. and D.H. each contributed to the conceptualization of the study, the data collection and analysis, and the writing of the manuscript. Ethics of buman subject participation: This study was conducted according to the guidelines laid down in the Declaration of Helsinki and all procedures involving human subjects were approved by the Bowling Green State University Institutional Review Board. Written informed consent was obtained from all participants.

\section{References}

1. Lumeng JC, Ozbeki TN, Appugliese DP et al. (2012) Observed assertive and intrusive maternal feeding behaviors increase child adiposity. Am J Clin Nutr 95, 640-647.

2. Scaglioni S, Arrizza C, Vecchi F et al. (2011) Determinants of children's eating behavior. Am J Clin Nutr 94, 6 Suppl., 2006S-2011S.

3. Zeinstra GG, Koelen MA, Kok FJ et al. (2010) Parental childfeeding strategies in relation to Dutch children's fruit and vegetable intake. Public Health Nutr 13, 787-796.

4. Blissett J (2011) Relationships between parenting style, feeding style and feeding practices and fruit and vegetable consumption in early childhood. Appetite 57, 826-831.

5. Holland JC, Kolko RP, Stein RI et al. (2014) Modifications in parent feeding practices and child diet during family-based behavioral treatment improve child zBMI. Obesity (Silver Spring) 22, E119-E126.

6. Papaioannou MA, Cross MB, Power TG et al. (2013) Feeding style differences in food parenting practices associated with fruit and vegetable intake in children from low-income families. J Nutr Educ Behav 45, 643-651.

7. O'Connor TM, Pham T, Watts AW et al. (2016) Development of an item bank for food parenting practices based on published instruments and reports from Canadian and US parents. Appetite 103, 386-395.

8. Vaughn AE, Tabak RG, Bryant MJ et al. (2013) Measuring parent food practices: a systematic review of existing measures and examination of instruments. Int J Behav Nutr Phys Act 10, 61.

9. Pinard CA, Yaroch AL, Hart MH et al. (2012) Measures of the home environment related to childhood obesity: a systematic review. Public Health Nutr 15, 97-109.

10. Vaughn AE, Ward DS, Fisher JO et al. (2016) Fundamental constructs in food parenting practices: a content map to guide future research. Nutr Rev 74, 98-117.

11. Musher-Eizenman D \& Holub S (2007) Comprehensive feeding practices questionnaire: validation of a new measure of parental feeding practices. J Pediatr Psychol 32, 960-972.

12. Anderson SE, Must A, Curtin C et al. (2012) Meals in Our Household: reliability and initial validation of a questionnaire to assess child mealtime behaviors and family mealtime environments. J Acad Nutr Diet 112, 276-284. 
13. Berlin KS, Davies WH, Silverman AH et al. (2011) Assessing family-based feeding strategies, strengths, and mealtime structure with the Feeding Strategies Questionnaire. $J$ Pediatr Psychol 36, 586-595.

14. Chambers S \& Nimon K (2018) Conducting survey research using Mturk. In Handbook of Research on Innovative Techniques, Trends, and Analysis for Optimized Research Methods, pp. 258-288 [VCX Wang and TG Reio Jr, editors]. Hershey, PA: IGI Global.

15. Berinsky AJ, Huber GA \& Lenz GS (2012) Evaluating online labor markets for experimental research: Amazon.com's Mechanical Turk. Polit Anal 20, 351-368.

16. Buhrmester M, Kwang T \& Gosling S (2011) Amazon's Mechanical Turk: a new source of inexpensive, yet high quality, data? Perspect Psychol Sci 6, 3-5.

17. Paolacci G, Chandler J \& Ipeirotis P (2010) Running experiments on Amazon Mechanical Turk. Judgm Decis Mak 5, 411-419.

18. Kiefner-Burmeister A, Hoffmann D, Zbur S et al. (2016) Implementation of parental feeding practices: does parenting style matter? Public Health Nutr 19, 2410-2414.

19. González-Vallejo C \& Lavins BD (2016) Evaluation of breakfast cereals with the current nutrition facts panel (NFP) and the Food and Drug Administration's NFP proposal. Public Health Nutr 19, 1047-1058.

20. Birch L, Fisher J, Grimm-Thomas K et al. (2001) Confirmatory factor analysis of the Child Feeding Questionnaire: a measure of parental attitudes, beliefs and practices about child feeding and obesity proneness. Appetite 36, 201-210.

21. Blissett J, Haycraft E \& Farrow C (2010) Inducing preschool children's emotional eating: relations with parental feeding practices. Am J Clin Nutr 92, 359-365.

22. Power TG (2013) Parenting dimensions and styles: a brief history and recommendations for future research. Child Obes 9, Suppl. 1, S14-S21.
23. Andaya AA, Arredondo EM, Alcaraz JE et al. (2011) The association between family meals, TV viewing during meals, and fruit, vegetables, soda, and chips intake among Latino children. J Nutr Educ Behav 43, 308-315.

24. Kratt P, Reynolds K \& Shewchuk R (2000) The role of availability as a moderator of family fruit and vegetable consumption. Health Educ Behav 27, 471-482.

25. Taylor MB, Emley E, Pratt M et al. (2017) Structure-based feeding strategies: a key component of child nutrition. Appetite 114, 47-54.

26. Frankel LA, Powell E \& Jansen EL (2017) The relationship between structure-related food parenting practices and children's heightened levels of self-regulation in eating. Child Obes 14, 81-88.

27. Moore SN, Tapper K \& Murphy S (2010) Feeding goals sought by mothers of 3-5-year-old children. Br J Health Psychol 15, 185-196.

28. Hurley KM, Cross MB \& Hughes SO (2011) A systematic review of responsive feeding and child obesity in highincome countries. J Nutr 141, 495-501.

29. Wardle J, Herrera M-L, Cooke L et al. (2003) Modifying children's food preferences: the effects of exposure and reward on acceptance of an unfamiliar vegetable. Eur J Clin Nutr 57, 341-348.

30. O'Connor TM, Mâsse LC, Tu AW et al. (2017) Food parenting practices for 5 to 12 year old children: a concept map analysis of parenting and nutrition experts input. Int J Behav Nutr Phys Act 14, 122.

31. Vaughn AE, Dearth-Wesley T, Tabak R et al. (2017) Development of a comprehensive assessment of food parenting practices: the home self-administered tool for environmental assessment of activity and diet family food practices survey. J Acad Nutr Diet 117, 214-227. 